\title{
Innovation after the revolution: foreign sovereign bond contracts since 2003
}

Anna Gelpern and Mitu Gulati*

\section{Key points}

- In 2003, under official pressure, amendment provisions in standard form New York law sovereign bond contracts shifted to resemble English law boilerplate.

- Market participants and officials expected contracts in New York and London to converge around a common formulation.

- Contrary to expectations, the shift away from old boilerplate did not lead to convergence around new boilerplate.

- Issuers in London, and to a lesser degree in New York, are experimenting with diverse terms and institutional arrangements.

- Amendment provisions in recent issues have used hybrid formulations, permitting holders to vote in person or by written consent, with different approval thresholds.

- More issuers are using trust structures.

- Creditor committees are making a qualified comeback, though the adoption and formulation of committee provisons does not appear to track issuers' credit quality.

- Not all issuers agree to pay committee expenses.

- Some issuers have agreed to require unanimous creditor consent to amend litigation-related terms, even as financial terms can still be amended by qualified creditor majorities.

- None of these variations conform to traditional theoretical explanations for boilerplate change, which credit leadership by large-volume market participants and official sector pressure. Nor were they inadvertent.

- The role of industry groups and the difference in innovation practice in New York and London merit further study.

\section{Introduction: theory's poster children}

Practitioners and academics agree: bond contract terms are highly standardized and hard to change. ${ }^{1}$ The dominant theory of contract change, based on network and learning analysis, posits that market participants value uniformity. Everyone uses standard terms; everyone knows what they mean. Market participants who trade boilerplate contracts have no trouble pricing them. Lawyers who draft contract boilerplate can predict how judges might interpret it. ${ }^{2}$ The down side of boilerplate is excess uniformity: change is

\footnotetext{
* Anna Gelpern and Mitu Gulati, Rutgers and Duke Law Schools.

1 See Marcel Kahan and Michael Klausner, 'Standardization and Innovation in Corporate Contracting (Or "The Economics of Boilerplate”)' (1997) 83 Va L Rev 713 (corporate bonds); see also Lee C. Buchheit, How to Negotiate Eurocurrency Loan Agreements, ch 2 (2nd edn, 2000) (sovereign and corporate loans).

2 Charles J. Goetz and Robert E. Scott, 'The Limits of Expanded Choice: An Analysis of the Interactions Between Express and Implied Contract Terms' (1985) 73 Cal L Rev 261.
} 
difficult to induce, even when the standard terms are suboptimal and technically easy to fix. Innovation takes work, costs money and signals deviance ${ }^{3}$ - the new term's meaning is uncertain, its proponents might be up to no good, and even if their motive is perfectly benign, convincing the broader market is a hassle rarely worth the benefit of any given term.

Recent contracts literature has suggested that network and learning effects make it hard for all but the biggest actors to bear the cost of switching from boilerplate. ${ }^{4}$ Only the highest volume issuers, bankers and lawyers can be confident that, if they switch clauses, the minnows will follow and a new standard will be set. ${ }^{5}$ The minnows, who have limited resources to innovate and cannot readily diffuse new clauses market-wide, will not switch on their own for fear of producing bonds that no one knows how to price and that no one wants to trade. We refer to this set of views on innovation as the 'Big Player Explanation'.

But even for the big fish, the innovation bar is high. Where contract change is a public good, the official sector-governments, government groupings and institutions such as the International Monetary Fund (IMF) — can cue a switch by reassuring the markets of the new standard's benefits and its prospects. ${ }^{6}$ We refer to this as the 'Official Sector Explanation'.

Both explanations were tested in the unlikely field of emerging market sovereign debt between 1996 and 2003. During this period, governments in middle-income and poor countries had over $\$ 300$ billion in outstanding bonds governed by New York and English law. ${ }^{7}$ New York law bonds contained provisions requiring the consent of every bondholder to amend payment terms. English law bonds let the same terms be amended with a relatively low bondholder majority. The difference matters because unlike corporate and individual debtors, states cannot restructure their debts in bankruptcy. No law and no judge can override the will of the bondholders. As a result, a typical

3 Omri Ben-Shahar and John A. E. Pottow, 'On the Stickiness of Default Rules' (2006) 33 Fla St U L Rev 651.

4 However, research on shareholder rights plans, poison pills and the adoption of LLP status reveals that deviation from convention can emerge from smaller and less established players. See Michael J. Powell, 'Professional Innovation: Corporate Lawyers and Private Lawmaking' (1993) 18 LSI 423; Scott Baker and Kimberly D. Krawiec, 'The Economics of Limited Liability' (2005) U Ill L Rev 107. In other areas of the law, scholars have found more willingness to experiment among smaller and lower status players. For example, in their study of Silicon Valley law firms, Phillips and Zuckerman found that firms at the top and the bottom of the corporate practice hierarchy were most likely to add a family law practice, which is traditionally low-status. Those at the top often had the most to gain from innovation and were comfortable with their position in the hierarchy, whereas those at the bottom had the least to lose and the most to gain from deviations. See Damon J. Phillips and Ezra W. Zuckerman, 'Middle-Status Conformity: Theoretical Restatement and Empirical Demonstration in Two Markets' (2001) 107 Amer J Soc 379.

5 Kahan and Klausner (n 1); Stephen J. Choi and G. Mitu Gulati, 'Innovation in Boilerplate Contracts: An Empirical Examination of Sovereign Bonds' (2004) 53 Emory L J 929.

6 Robert B. Ahdieh, 'Between Mandate and Market: Contract Transition in the Shadow of the International Order' (2004) 53 Emory L.J. 691, 735.

7 Gloria M. Kim, EMBI Global and EMBI Global Diversified: Rules and Methodology. J. P. Morgan Securities Inc., December 2004 (on file with authors). In mid-2003, the largest countries in the EMBI Global were Brazil, Mexico and Russia. Jonathan Bayliss, Emerging Markets as an Asset Class. J. P. Morgan Securities Inc., September 2003 (on file with authors). Other countries frequently included are Argentina, Bulgaria, Chile, China, Colombia, Cote d'Ivoire, the Dominican Republic, Ecuador, Egypt, El Salvador, Hungary, Indonesia, Lebanon, Malaysia, Morocco, Nigeria, Pakistan, Panama, Peru, the Philippines, Poland, Serbia, South Africa, South Korea, Tunisia, Turkey, Ukraine, Uruguay, Venezuela and Vietnam. The older EMBI+ index includes fewer countries, has higher liquidity requirements than EMBI Global, and excludes certain debt of parastatals and local governments. EMBI Global Diversified includes the same countries as EMBIG, but caps the weighting of the largest issuers within the index. Kim, Ibid. 
New York law sovereign bond circa 1996 on its face gave each bondholder a veto over debt restructuring.

This was not a theoretical problem: for over a century, emerging market sovereigns have defaulted and restructured with depressing regularity. ${ }^{8}$ In the early days, absolute sovereign immunity protected them from disgruntled creditors. In the 1980s debt crisis, the creditors were overwhelmingly commercial banks. Banks were fewer and more likely to have a long-term interest in the borrowing country. Their contracts were more flexible than standard-form bonds. And they were willing to take a call from their finance minister urging gentlemanly behaviour for the common good. The bondholders that replaced banks in the 1990s were none of the above. Officials, lawyers and economists worried aloud that in a crisis, the unanimous consent term in New York law bonds would create holdout problems, exacerbate the effects of default and prolong economic decline. $^{9}$

Unanimity was a matter of custom, not law, in New York. Nevertheless, it proved sticky. Beginning in 1996, the official sector launched a series of campaigns to promote the shift to 'collective action clauses' (CACs) in New York law sovereign bonds as a central part of its agenda for managing financial crises. Majority amendment topped the CAC list. Officials called, cornered and cajoled finance ministers and their bankers. They jawboned financial industry groups and sponsored drafting committees of 'eminent lawyers' from jurisdictions around the globe. They promised to establish an international bankruptcy regime that would bind holdouts by fiat. ${ }^{10}$ The market would not budge: even creditors who held billions of dollars in English-law bonds with majority modification terms resisted departure from unanimity under New York law. ${ }^{11}$

In 2003, with the threat of statutory sovereign bankruptcy hanging over the markets, Mexico issued \$1 billion in New York law bonds allowing modification of payment terms with the consent of $75 \%$ of outstanding principal amount of the issue (Box 1). The move was hailed as a watershed by officials and market participants alike. At the time, Mexico was one of the largest and strongest issuers in the emerging market asset class. ${ }^{12}$ The investment bankers and lawyers who worked on the deal were from the largest volume firms in the business: Goldman Sachs, JP Morgan, Cleary, Gottlieb, Steen \& Hamilton and Sullivan \& Cromwell. ${ }^{13}$ If theory needed proof, it could find no better: a widely

\footnotetext{
8 See Carmen M. Reinhart, Kenneth S. Rogoff and Miguel A. Savastano, 'Debt Intolerance' (2003) BPEA 1.

9 Group of Ten, The Resolution of Sovereign Liquidity Crises: A Report to the Ministers and Governors Prepared under the Auspices of the Deputies (1996) (hereinafter Rey Report) <http://www.bis.org/publ/gten03.pdf> (accessed 19 November 2008). Barry Eichengreen et al., Crisis? What Crisis? Orderly Workouts for Sovereign Debtors (1995); James Hurlock and Troy Alexander, 'The Fire Next Time: The Dangers in the Next Debt Crisis' (1996) 15 IFLR 14; Lee C. Buchheit, 'Making Amends for Amendments' (1991) 10 IFLR 11; Lee C. Buchheit and G. Mitu Gulati, 'Sovereign Bonds and the Collective Will' (2003) 51 Emory L J 1317. 10 Gelpern and Gulati (n 10).

11 Rey Report (n 9); William W. Bratton and G. Mitu Gulati, 'Sovereign Debt Reform and the Best Interest of Creditors' (2004) 57 Vand L Rev 1, 56-61; Anna Gelpern and G. Mitu Gulati, 'Public Symbol in Private Contracts: A Case Study' (2006) 84 Wash U L R 1627.

12 Kim, (n 7). In mid-2003, the largest countries in the EMBI Global were Brazil, Mexico and Russia. Jonathan Bayliss, Emerging Markets as an Asset Class. J. P. Morgan Securities Inc., September 2003 (on file with authors).

13 Choi and Gulati (n 5).
} 


\section{Box 1}

\section{Mexico's Collective Action Clause}

[Excerpted from Pricing Supplement, United Mexican States, \$1,000,000,000, 6.625 per cent Notes Due 2015 (26 February 2003)]

\section{Meetings, amendments and waivers}

Mexico may call a meeting of the holders of the notes at any time regarding the fiscal agency agreement or the notes. Mexico will determine the time and place of the meeting. Mexico will notify the holders of the time, place and purpose of the meeting not less than 30 and not more than 60 days before the meeting.

In addition, the fiscal agent will call a meeting of the holders of the notes if the holders of at least 10 per cent of the aggregate principal amount of the outstanding notes have delivered a written request to the fiscal agent setting forth the action they propose to take. The fiscal agent will notify the holders of the time, place and purpose of any meeting called by the holders not less than 30 and not more than 60 days before the meeting.

Only holders of notes and their proxies are entitled to vote at a meeting of holders. Holders or proxies representing a majority of the aggregate principal amount of the outstanding notes will normally constitute a quorum. However, if a meeting is adjourned for a lack of a quorum, then holders or proxies representing 25 per cent of the aggregate principal amount of the outstanding notes will constitute a quorum when the meeting is rescheduled. For purposes of a meeting of holders that proposes to discuss reserved matters, which are specified below, holders or proxies representing 75 per cent of the aggregate principal amount of the outstanding notes will constitute a quorum. The fiscal agent will set the procedures governing the conduct of the meeting.

Mexico, the fiscal agent and the holders may generally modify or take actions with respect to the fiscal agency agreement or the terms of the notes:

- with the affirmative vote of the holders of not less than $662 / 3$ per cent of the aggregate principal amount of the outstanding notes that are represented at a meeting; or

- with the written consent of the holders of $662 / 3$ per cent of the aggregate principal amount of the outstanding notes.

However, the holders of not less than 75 per cent of the aggregate principal amount of the outstanding notes (emphasis added), voting at a meeting or by written consent, must consent to any amendment, modification, change or waiver with respect to the notes that would:

- change the due dates for the payment of principal of or interest on the notes;

- reduce any amounts payable on the notes; 
- reduce the amount of principal payable upon acceleration of the maturity of the notes;

- change the payment currency or places of payment for the notes;

- permit early redemption of the notes or, if early redemption is already permitted, set a redemption date earlier than the date previously specified or reduce the redemption price;

- reduce the percentage of holders of the notes whose vote or consent is needed to amend, supplement or modify the fiscal agency agreement (as it relates to the notes) or the terms and conditions of the notes or to take any other action with respect to the notes or change the definition of 'outstanding' with respect to the notes;

- change Mexico's obligation to pay any additional amounts;

- change the governing law provision of the notes;

- change the courts to the jurisdiction of which Mexico has submitted, Mexico's obligation to appoint and maintain an agent for service of process in the Borough of Manhattan, The City of New York or Mexico's waiver of immunity, in respect of actions or proceedings brought by any holder based upon the notes, as described in the prospectus;

- in connection with an exchange offer for the notes, amend any event of default under the notes; or

- change the status of the notes, as described under 'Description of the SecuritiesDebt Securities-Status' in the prospectus.

We refer to the above subjects as 'reserved matters'. A change to a reserved matter, including the payment terms of the notes, can be made without your consent, as long as a supermajority of the holders (that is, the holders of at least 75 per cent of the aggregate principal amount of the outstanding notes) agree to the change.

criticized provision stuck until the biggest market players teamed up with the world's most powerful governments to implement and spread a fix.

Mexico's adoption of majority amendment provisions in February 2003 fit both the Big Player and the Official Sector explanations. But it soon turned out that Mexico was not first. Earlier CAC users, uncovered by researchers from the Reserve Bank of Australia, were relatively marginal issuers like Kazakhstan and Lebanon, who used majority amendment in New York law bonds as early as $1997 .{ }^{14}$ These issuers appeared to have no knowledge of the official campaign for CACs; they did little to publicize their innovations, and showed no desire to diffuse or take credit for them. And in the course of our own research, practitioners showed us examples of CACs in New York law paper 
going back to $1983,{ }^{15}$ predating official engagement by more than a decade. No one recalled the reasons for the clauses' inclusion.

The authors of the Australian study that first uncovered pre-Mexico CACs speculated that they were inadvertent-a product of form-copying by US law firms in the London market. They cited these early cases as evidence of the CACs' unimportance. ${ }^{16}$ Their paper implied a view of contractual innovation different from both the Big Player and the Official Sector explanations. We refer to it as the 'Inadvertence Explanation'.

In hindsight, Mexico offers at best qualified support for the prevailing theories of legal innovation, and leaves many questions unanswered. This article offers a glimpse at the evolution of sovereign bond contracts after Mexico. Five years later, the press corps has decamped and the officials have moved on. We set out to study a recent crop of contracts to determine whether the boilerplate effect had locked in. Based on our review of recent filings available on the Thomson Financial database, as of this writing, our impression is that, while most issuers in New York have coalesced around a handful of models_primarily Mexico's first issue in 2003-and active experimentation continues among relatively small issuers in the London market for both New York and English law bonds. ${ }^{17}$ This in turn raises the possibility that pre-Mexico CACs were not an aberration at all—or a product of mindless form-copying—but reflect a distinct mode of contractual innovation.

For over a decade, the contracts literature has focused on the phenomenon of standardization. Scholars asked how terms become standard, and why they change so rarely. The emphasis on standardization painted a world where a standard term persists until it is dislodged by another standard term, perhaps after a brief window of ferment before the second term takes hold. But this framing overshadowed the early insights of boilerplate theories, which described contracts as a mix of standard and customized terms. Judicial interpretation attitudes, or network and learning effects, may prompt suboptimal combinations. Our examples, along with the pre-Mexico CACs and recent research on dispute resolution terms in sovereign debt contracts, ${ }^{18}$ bring the focus back to the mix. The contracts we study suggest that standardization may be a matter of degree, that the degree of standardization may vary across different markets, and that a shock of the sort that led to Mexico's 2003 issue may dislodge a previously standard term without replacing it with a new standard—erstwhile boilerplate becomes a platform for customization.

In what follows, we summarize several variations on CACs introduced since 2003, and try to shed light on the forces that brought them into being. To find out how the new clauses came about, we spoke to lawyers, bankers and officials in the field, and asked

15 Republic of Indonesia, \$250,000,000 Floating Rate Notes due 1993, Prospectus dated 22 September 1983, 10.

16 Ibid.

17 In our study, we examine contractual terms as reported in the offering documents (offering circulars, prospectuses and supplements).

18 Mark C. Weidemaier, 'Disputing Boilerplate' (unpublished draft dated July 2008) <http://papers.ssrn.com/sol3/papers. cfm?abstract_id=1158611> (accessed 19 November 2008). 
them about their models, their negotiations, and the influence of academics, trade associations and the official sector on the deals. Chastened by the belated discoveries of pre-Mexico CACs, we do not claim that the clauses in our case studies are the first of their kind. In many cases, we point out that they are not. However, they do represent departures from what academics, officials and many practitioners appear to regard as boilerplate.

\section{Boilerplate in flux}

\section{To meet or not to meet: Gabon and Ghana}

Before 2003, holders of New York law sovereign bonds could, in theory, amend the financial terms of their bond contracts by mailing a ballot to that effect to the fiscal agent of the sovereign issuer. Because every single holder had to vote in favour of the amendment (abstentions count as votes against), any such effort was doomed to failure, which may explain why no sovereign had ever bothered to test the process. Instead, New York law bonds containing unanimity provisions were restructured in debt exchanges: participating creditors exchanged old contracts for new ones with different terms; their old contracts were cancelled. Dissenters kept the old bonds, were free to sue, and were usually paid off in accordance with the old terms. ${ }^{19}$

Standard-form English law contracts provided for amendment at bondholder meetings. Financial terms could normally be changed by a vote of 75 per cent of a bondholder quorum. The quorum ranged from 75 per cent to 25 per cent of outstanding principal at a postponed meeting. In theory, this allowed debt restructuring with the blessing of less than 20 per cent of the debt. Dissenters were bound to the new terms. But creditor meetings could be a double-edged sword. One of the early emerging market bond exchanges of the 1990s, which targeted English law contracts, was structured to preempt a face-to-face meeting for fear that creditors acting collectively were more likely to rebel. Ukraine asked participating holders to give their proxy to the restructuring agent, but no meeting could be called until proxies representing 75 per cent of the total were received. ${ }^{20}$

Mexico's February 2003 issue under New York law permitted amendment of financial terms and several other provisions ('Reserved Matters') with the consent of creditors holding 75 per cent of outstanding principal obtained in writing or at a meeting. ${ }^{21}$ For non-reserved matters, the threshold varied depending on whether the vote was taken at a meeting (English model) or in writing (New York model). Mexico's formulation appears to have become standard in New York. Variations were rare. Uruguay's introduction of aggregation provisions, which allowed simultaneous amendment of

19 See Lee C. Buchheit, 'How Ecuador Escaped the Brady Bond Trap' (2000) 19 IFLR 17.

20 Federico Sturzenegger and Jeromin Zettelmeyer, Debt Defaults and Lessons from a Decade of Crises (2006) 128.

21 'Mexico Prospectus', Pricing Supplement, United Mexican States, \$1,000,000,000, 6.625\% Notes Due 2015 (26 February 2003) PS-7. <http://www.sec.gov/Archives/edgar/data/101368/000095012303002091/y83744b3e424b3.htm> (accessed 19 November 2008) 
multiple issues, was the most notable among these; it has since been adopted by Argentina and several smaller issuers. ${ }^{22}$

In December 2007, The Gabonese Republic, a small, oil-rich African dictatorship, issued $\$ 1$ billion in notes in London, governed by New York law. ${ }^{23}$ The issue was Gabon's first in recent memory; the notes were rated BB-by Standard \& Poors and Fitch Ratings, a speculative investment. Nevertheless, Gabon apparently secured more flexibility in its amendment provisions than Mexico, a much larger, investment-grade oil exporter with a glowing reputation for professionalism in debt management. Should Gabon wish to amend key terms of its bonds, it may solicit the written consent of 75 per cent of outstanding principal—or use the traditional English approach of calling a meeting and winning over 75 per cent of a quorum. ${ }^{24}$ With the lower quorum requirement for a postponed meeting, Gabon could in theory restructure the notes with a mere 25 per cent of its creditors, binding the rest. Gabon's combination of English and New York CAC styles was unusual. ${ }^{25}$ It was made possible in part because this New York law bond was being offered in the United Kingdom, to investors familiar and comfortable with the UK style meeting provisions.

The combined formulation reflects an implicit tradeoff. If the issuer seeks to restructure by mail, it must deal with a higher voting threshold, and the fact that inattentive bondholders who fail to cast their ballots count as votes against modification. On the other hand, if it is willing to look bondholders in the eye at a meeting and risk catalysing creditor rebellion, Gabon might benefit from a lower amendment threshold.

Shortly before Gabon went to market with its New York-law issue, the Republic of Ghana, another speculative-grade African borrower, sold $\$ 750$ million in notes governed by English law. ${ }^{26}$ Ghana's amendment provisions are like Gabon's-blending what had been distinct New York and English law conventions. Creditors can vote to change Reserve Matters in writing, which requires 75 per cent of outstanding principal, or meet and amend with 75 per cent of the quorum (two-thirds of outstanding principal, reduced to one-third by postponement).

Gabon's and Ghana's CACs appear to contradict all three of the explanations for boilerplate change that we flagged earlier. They were small and weak players in the sovereign debt market. Their lawyers were highly regarded, but did not stand out for the sheer volume of their sovereign representation in the way that Mexico's lawyers Cleary, Gottlieb had in New York. ${ }^{27}$ Citi co-managed both Gabon's and Ghana's issues and has

22 Voting thresholds for reserved matters initially ranged from $75 \%$ to $90 \%$, but by and large have settled around $75 \%$.

23 Prospectus, The Gabonese Republic, \$1,000,000,000, 8.2\% Notes Due 2017 (5 December 2007).

24 Gabon Prospectus (n 23) 90.

25 Shortly before the Gabon issue in London, Grenada issued a bond in New York borrowing some features of English law—most importantly, removing the individual right to sue. See Lee C. Buchheit and Elizabeth Karpinski, 'Grenada's Innovations' (2006) $21 \mathrm{~J}$ Intl Bank Regul 227. Lee Buchheit, the term's author and a large-volume intermediary himself, noted that this was the first case of combining US and English-law forms in recent memory.

26 Offering Circular, The Republic of Ghana, \$750,000,000, 8.5\% Notes Due 2017 (2 October 2007).

27 Choi and Gulati (n 5). 
been prominent in the sovereign market for some time; however, we found no indication that the lead managers in either deal had expressed a preference for this particular CAC formulation, nor did we discern any broader consistency among Citi-managed sovereign issues. The Big Player Explanation appears implausible. The Official Sector Explanation does no better. Our interviews for this project, in contrast to our earlier investigation of Mexico's CAC issue in 2003, revealed no pressure from the IMF, the US Treasury and the Bank of England to induce these modifications. Our official contacts seemed largely unaware of them. The remaining hypothesis-Inadvertence-was vigorously contradicted by the lawyers involved in the deals. ${ }^{28}$ All appear to have been cognizant of what they were doing and why_including reasons for using different thresholds for votes taken in meetings and in writing - and some recounted negotiations leading up to the CAC formulas they used. In both London-based deals, the participants had closely followed the debates over New York CACs, read private sector and official reports on the clauses, and said that they consciously selected aspects of US documentation practice that they considered sensible and favourable.

\section{Committees return: from Hungary to Georgia, via Abu Dhabi}

Sovereign bond restructuring is a venerable practice-it goes back over 100 years. However, until the middle of the 20th century, bondholders could not sue defaulting sovereigns in court. ${ }^{29}$ Lobbying their own governments was usually their only path to recovery. To that end, creditors in the United Kingdom and later in the United States organized bondholder protective committees to coordinate their approach to the debtors and their own foreign ministries. ${ }^{30}$ After a nasty series of defaults in the 1930s, the sovereign bond market died for half a century. When middle-income developing countries returned to the markets in the 1970s, they borrowed from commercial banks in the form of syndicated loans. Beginning in 1982, the loans were restructured through bank advisory committees, where the largest banks with the greatest exposure to the distressed debtor coordinated the rest, advised by lawyers and other experts hired at the sovereign's expense. ${ }^{31}$

The return of sovereign bonds on a large scale in the early 1990s and the return of sovereign bond restructuring a few years later marked a change: for the first time in recent memory, issuers faced a large, diffuse group of bondholders that had no centralized representation and no apparent means of coordinating among themselves. The prevailing wisdom was that a dispersed creditor body would encourage holdout behaviour and hurt the debtor. ${ }^{32}$ Sovereigns responded with unilateral exchange offers

28 A critic might point out that, of course, lawyers would never concede inadvertence. In our conversations, the lawyers went beyond simply denying inadvertence, sharing specific models, tables comparing different formulations and negotiation anecdotes explaining why they had made the relevant changes.

29 Letter from Jack B. Tate, Acting Legal Adviser, Department of State, to Acting A-G Philip B. Perlman (19 May 1952), reprinted in 26 Dept St Bull 984, 984-85 (1952).

30 For a summary, see Rory Macmillan, 'Towards a Sovereign Debt Work-out System' (1995) 16 Nw J Intl L Bus 57, 80-84.

31 See Alfred Mudge, 'A Perspective of Counsel to Agent Banks, Bank Advisory Groups and Servicing Banks' in William N. Eskridge Jr (ed.), A Dance Along the Precipice: The Political and Economic Dimensions of the International Debt Problem (1985). 32 Gelpern and Gulati (n 10). 
that built on more-or-less broad-based outreach to creditors. In all but one recent case, these offers attracted over 85 per cent of the bondholders. ${ }^{33}$ Argentina was the exception, with just over three-quarters of the holders participating. In this largest and most contentious restructuring in recent history, groups of domestic and foreign creditors tried to organize themselves in various ways, but ultimately proved unable to bind one another and, for the most part, accepted Argentina's terms. ${ }^{34}$

Beginning in the mid-1990s, some practitioners, academics and officials called for reviving creditor committees to coordinate within and among different debt issues. ${ }^{35}$ However, these calls did not get enough support to be among the CACs drafted by a panel of 'eminent lawyers' representing debtors and creditors under the auspices of the Group of Ten (G-10). ${ }^{36}$ Instead, the eminent ones advocated coordinating creditors within a single debt instrument using trust structures and permitted the appointment of a creditor representative to engage in restructuring negotiations. ${ }^{37}$ Early CAC issuers in New York similarly rejected committees. But some creditor groups and veterans of 1980s restructurings persisted. Creditor committees were discussed in the 2004 Principles for Stable Capital Flows and Fair Debt Restructuring in Emerging Markets (the Principles), endorsed by two large-trade associations and a group of emerging markets issuers. ${ }^{38}$ The Principles did not take a firm position on the merits of committees as a means of creditor organization, but noted that in the past, issuers had paid committee expenses. Unlike the G-10 clauses, model clauses produced by one of the trade groups included a committee provision (Box 2).

None of the prominent sovereigns endorsing the Principles changed their contracts to provide for committees or any other version of the engagement clause. Several smaller emerging market issuers in New York used trust structures on the G-10 model, as did Spain and the United Kingdom (reportedly to advance good documentation

33 Ibid, 91, n 407.

34 Giselle Datz, 'What Life after Default? Time Horizons and the Outcome of the Argentine Debt Restructuring Process' RIPE (arguing that creditor dispersion favours the sovereign); Anna Gelpern, After Argentina (Inst. for Intl Econ., Policy Brief No. PB0502, 2005), <http://www.iie.com/publications/pb/pb05-2.pdf> (accessed 19 November 2008) (observing that creditor committees formed during Argentina's restructuring quickly broke ranks).

35 Macmillan (n 30); Eichengreen et al., (n 9); John B. Taylor, 'Under Secretary of Treasury for International Affairs, Sovereign Debt Restructuring: A US Perspective', Speech at the Conference on Sovereign Debt Workouts: Hopes and Hazards, Institute for International Economics (2 April 2002) <http://www.iie.com/publications/papers/paper.cfm?ResearchID=455> (accessed 19 November 2008), Banque de France Staff, 'Towards a Code of Good Conduct on Sovereign Debt Re-Negotiation' (January 2003) <http://www.banque-france.fr/gb/publications/telechar/rsf/2003/etud7_0603.pdf > (accessed 17 November 2008). The French central bank proposal was incorporated in the Principles for Stable Capital Flows and Fair Debt Restructuring in Emerging Markets ('Principles'). The Principles were released jointly by the Institute of International Finance, International Primary Markets Association (since merged into International Capital Markets Association), and several key emerging markets issuers in the fall of 2004. See Inst. Of Intl Fin., 'Principles for the Emerging Markets' <http://www.iif.com/emp/principles/> accessed 19 September 2008; Press Release, Sovereign Issuers of International bonds, the Inst. of Intl Fin., and the Intl Primary Mkt. Assoc., Key Principles Agreed To Strengthen Emerging Markets Finance (22 November 2004) <http://www.icma-group.org/getdoc/ e316e335-c63d-4fca-9801-def086bf7ecd/221104-Principles-Pressrelease-PDF.aspx? > (accessed 17 November 2008).

36 Group of Ten, 'Report of the G-10 Working Group on Contractual Clauses' (26 September 2002) <http://www.bis.org/publ/ gten08.pdf $>$ (accessed 19 November 2008).

37 Ibid. The restructuring representative term does not mention expenses. Different representation structures are compared in Lee C. Buchheit, 'The Collective Representation Clause' (1998) 17 IFLR 9.

38 The Principles (n 35). 


\section{Box 2}

\section{ICMA Model Creditor Committee Clause}

[Excerpted from the International Capital Market Association Standard Collective Action Clauses for Terms and Conditions of Sovereign Notes (English Law, Fiscal Agency Structure) 28 October 2004] ${ }^{\mathrm{a}}$

\section{[•] Noteholders' Committee}

(a) Appointment: the Noteholders may, by a resolution passed at a meeting of Noteholders duly convened and held in accordance with the Fiscal Agency Agreement by a majority of at least 50 per cent in aggregate principal amount of the Notes then outstanding, or by notice in writing to the Issuer (with a copy to the Fiscal Agent) signed by or on behalf of the holders of at least 50 per cent in aggregate principal amount of the Notes then outstanding, appoint any person or persons as a committee to represent the interests of the Noteholders if any of the following events has occurred:

(i) an event of default;

(ii) any event or circumstance which could, with the giving of notice, lapse of time, the issuing of a certificate and/or fulfilment of any other requirement provided for in Condition [•] ('events of default') become an event of default; or

(iii) any public announcement by the Issuer, to the effect that the Issuer is seeking or intends to seek a restructuring of the Notes (whether by amendment, exchange offer or otherwise), provided, however, that no such appointment shall be effective if the holders of more than 25 per cent of the aggregate principal amount of the outstanding Notes have either:

(A) objected to such appointment by notice in writing to the Issuer (with a copy to the Fiscal Agent) during a specified period following notice of the appointment being given (if such notice of appointment is made by notice in writing to the Issuer) where such specified period shall be either 30 days or such other longer or shorter period as the committee may, acting in good faith, determine to be appropriate in the circumstances, or

(B) voted against such resolution at a meeting of Noteholders duly convened and held in accordance with the Fiscal Agency Agreement. Such committee shall, if appointed by notice in writing to the Issuer, give notice of its appointment to all Noteholders in accordance with Condition [•] ('Notices') as soon as practicable after the notice is delivered to the Issuer. 
(b) Powers: such committee in its discretion may, among other things,

(i) engage legal advisers and financial advisers to assist it in representing the interests of the Noteholders,

(ii) adopt such rules as it considers appropriate regarding its proceedings,

(iii) enter into discussions with the Issuer and/or other creditors of the Issuer,

(iv) designate one or more members of the committee to act as the main point(s) of contact with the Issuer and provide all relevant contact details to the Issuer,

(v) determine whether or not there is an actual or potential conflict of interest between the interests of the holders of the Notes then outstanding and the interests of the holders of debt securities of any one or more other series issued by the Issuer and

(vi) upon making a determination of the absence of any actual or potential conflict of interest between the interests of the holders of the Notes then outstanding and the interests of the holders of debt securities of any one or more other series issued by the Issuer, agree to transact business at a combined meeting of the committee and such other person or persons as may have been duly appointed as representatives of the holders of securities of each such other series.

Except to the extent provided in this paragraph (b) ('Powers'), such committee shall not have the ability to exercise any powers or discretions which the Noteholders could themselves exercise.

The Issuer shall pay any fees and expenses which are reasonably incurred by any such committee or any such combined committee (including, without limitation, the costs of giving notices to Noteholders, fees and expenses of the committee's legal advisers and financial advisers, if any) within 30 days of the delivery to the Issuer of a reasonably detailed invoice and supporting documentation.

${ }^{a}$ http://www.icmagroup.org/market_practice/Advocacy/collective_action/eu_collective_action.html (accessed 19 November 2008).

practices)_but none of them used committees. ${ }^{39}$ Beginning in 2004, smaller middleincome issuers like Hungary, Latvia, Macedonia, Serbia and Slovakia, and a few wealthy ones like Abu Dhabi and Sweden, gave bondholders an option to establish committees for their issue, and to deputize them to interact with other creditors in a debt restructuring. With the exception of two offerings in the United States, the practice appears largely confined to London, and is not standard even there. ${ }^{40}$ In their 2007 English law offerings,

39 As has Spain in its Multi Term Note filing done in October 2004. In the US context, as we discuss later, Iraq used a trust structure in its post-Saddam restructuring.

40 Hungary's issue with committees under New York law is an exception, along with the more recent issuance by Congo in April 2008; we discuss it below. Prospectus Supplement, Republic of Hungary, \$1,500,000,000, 4.75\% Notes Due 2015 (1 January 2005) 
for example, Austria, Ghana, Pakistan and Morocco, failed to provide for committees, or to include any other form of an engagement clause.

The Republic of Georgia is one of the most recent sovereigns to provide for committees; it did so in its April 2008 offering in London. Closely tracking the trade association model advanced in conjunction with the Principles, Georgia permits 50 per cent of its Noteholders, acting in writing or at a meeting, to establish a committee after an Event of Default, an adverse development that could become an Event of Default, or announcement of debt restructuring plans. The committee may hire professional advisers and negotiate with the issuer and other creditor groups. Georgia agreed to pay expenses. $^{41}$

The clause is generally perceived as creditor-friendly; it would be most valuable to creditors facing a real probability of restructuring in the near term. Therefore, it might be expected to appear among the riskiest borrowers. ${ }^{42}$ Georgia fits the bill: it is a speculativegrade issuer that has suffered non-stop civil strife and conflict with Russia since its independence in 1991. ${ }^{43}$

Yet, the broader pattern of engagement clause adoption in London and its selective adoption in New York do not support this explanation. One of the world's richest states, Abu Dhabi, agreed to committees. On the other hand, neither Gabon nor Ghana did. Investors and managers there showed no sign of demanding them. The most notable variation on engagement involves Hungary: an investment-grade borrower, it used engagement clauses in its late 2004 and early 2005 offerings. ${ }^{44}$ The 2004 English law offering document discloses the usual industry-model engagement clause; however, less than a year later, Hungary's New York law issue included an engagement clause without an undertaking to pay the committee's expenses. Hungary may have used its creditworthiness and the growing appetite for emerging market debt at the time to take the bite out of the clause. But the beleaguered Republic of Congo (Congo-Brazzaville), issuing New York law bonds out of a restructuring in 2007, also avoided committing to pay committee expenses: under Congo's indenture, the issuer is not obligated to recognize the committee, and does not pay its expenses until after recognition. On the other hand, issuers like Abu Dhabi, with as much or more bargaining power than Hungary, either did not try, or tried and failed to change the expense term.

Even without the engagement clause, nothing prohibits bondholders from appointing a representative or a committee to act for them. Limiting the circumstances under which a committee could be appointed without the offsetting benefit of expense reimbursement

and The Republic of Congo as Issuer and HSBC Bank USA, N.A., Trust Indenture dated as of 15 November 2007, U.S. Dollar Notes Due 2029, 41.

41 Prospectus, Georgia, \$750,000,000, 7.5\% Notes Due 2013 (11 April 2008) 80.

42 Cf. Barry Eichengreen and Ashoka Mody, 'Would Collective Action Clauses Raise Borrowing Costs?'(2000) National Bureau of Economic Research, Working Paper No. $7458<$ http://www.nber.org/papers/w7458.pdf > (accessed 19 November 2008). This early study of majority amendment provisions argues that poorly rated issuers would be the most likely to suffer a price penalty when departing from unanimity.

43 Georgia Prospectus (n 41) 10-11.

44 Offering Circular, Republic of Hungary, Euro 1,000,000,000, 4.5\% Notes Due 2014 (28 January 2004); Hungary Prospectus Supplement (n 40). 
arguably turns engagement into a pro-debtor term. At best, such a clause provides a roadmap for creditor coordination, and may shame the debtor on the margins into talking to its creditors. Some creditor representatives told us this symbolic function was critical. Others were sceptical. Neither the documents nor our interviews offer a coherent explanation for the differences among the issuers using the clause. One practitioner suggested that the market was going through a temporary period of experimentation.

With engagement clauses as with the rest, the prevailing explanations for boilerplate change fail to account for the sporadic pattern of adoption of engagement clauses. Few of the adopters were Big Players or intermediaries in the relevant market. No one sought to trumpet their use of engagement or to diffuse it for the sake of enhancing their market reputation. The Official Sector-the IMF and the Bank of England-monitored adoption, but did not press for committees. ${ }^{45}$ At least for the earliest adopters in 2004-2005, inadvertence did not apply: engagement provisions were new; there were no old contracts to cut and paste.

To date, the model language drafted by the International Primary Market Association [IPMA, now part of the International Capital Market Association (ICMA)] prevails among the adopters. Unlike other trade association drafting efforts described in the contracts literature, this set of model terms did not codify existing practice, but attempted to change it ${ }^{46}$ - with some success. However, association officials closely associated with the drafting effort insisted that they did not drive the diffusion, partly because trade groups disagreed among themselves. The groups' influence in individual deals is hard to gauge. No one claimed to have adopted the engagement clause in deference to industry preference, though many were aware of industry support. Some cited investor demand, especially among bondholders who went through Argentina's bruising restructuring. Some lawyers argued that in the absence of a trust structure, committees may facilitate discussions between the debtor and creditors as a group in the event of a default, and were therefore worth the expense. But some issuers, notably Congo-Brazzaville, had both a trust structure and an engagement clause. Several issuer lawyers who rejected engagement clauses countered that such clauses achieved little: the committees had limited power to negotiate, while multiple committees risked working at cross-purposes, and complicating a workout at the issuer's expense. At this writing, English law bonds issued by Seychelles are being restructured using a committee constituted under the bonds. In an ironic twist, the creditors are represented by a prominent issuers' counsel. The lead creditor Lehman Brothers, filed for bankruptcy reorganization in the middle of the restructuring talks. The experience may change the market's view of engagement clauses going forward.

45 The United Kingdom's use of trust structures in its own bonds was an attempt to lead by example, to promote the diffusion of the trust structure in emerging markets bonds.

46 Goetz and Scott (n 2); Kevin E. Davis, 'The Role of Nonprofits in the Production of Boilerplate' (2006) 104 Mich L Rev 1075 for a broader discussion of the nonprofits' role. Groups such as the International Swaps and Derivatives Association (ISDA) and the International Chamber of Commerce (ICC) generally portray their efforts as codifying and standardizing existing market practices. No issuer had used creditor committees before IPMA and IIF put forward their version of the engagement clause. 


\section{Unanimity revival}

Perhaps the most peculiar recent variation on CACs is the quiet revival of unanimous consent to modify a subset of contract terms. At least four sovereigns, Georgia, Lithuania, Serbia and Seychelles agreed to give every bondholder the right to veto changes to contract terms that may affect creditor capacity to sue the issuer. For example, in Georgia's case, changing choice of law, consent to jurisdiction, maintaining an agent for service of process and waiver of sovereign immunity all require unanimous consent. ${ }^{47}$ The payment terms of Georgia's bonds may be changed with the consent of 75 per cent of outstanding principal amount. If it were to get the 75 per cent approval, the Republic of Georgia could 'amend' the principal amount of its notes to reduce it to zero. But Georgia cannot change the governing law from English to New York unless every single one of its creditors is awake and favourably inclined.

The move to unanimity is puzzling: it had taken years of effort to get the US market to follow the UK majority amendment model. And now, after the US market had abandoned unanimity, issuers in the United Kingdom were embracing it? One explanation we heard was that unanimity aims to assuage small investors' fear of being outvoted by large ones, with more bargaining power to secure restructuring terms they liked. In this context, the small dissenters would at least retain the capacity to sue. Yet it is difficult to see what they would sue for once the financial terms had been amended. And even if the new unanimity provision succeeded at protecting the small litigant, this goal is itself diametrically opposed to a central goal of the CAC campaign: blocking minority holdout litigation. A truly effective provision enabling minority holdout litigation would revive the rigidities of the pre-2003 New York practice; New York and London would switch places.

The roots of unanimity requirements for non-financial terms likely go back to Ecuador's use of exit consents in its 1999 Brady bond exchange. Before financial terms in New York law bonds could be amended by a qualified majority, Ecuador's lawyers borrowed a corporate debt restructuring tactic: they asked creditors participating in the exchange to vote on their way out to amend bond terms that were not subject to unanimity. ${ }^{48}$ Under the drafting convention of the day, these included status (priority), governing law, choice of forum and submission to jurisdiction, among others. Thus amended, the old bonds became effectively unenforceable. Fear of being left holding worthless bonds boosted participation, but enraged some bondholders. ${ }^{49}$ One New Yorkbased creditor association proposed raising the threshold for amending such provisions to 95 per cent, on par with its proposal for financial terms. London-based IPMA proposed unanimity. IPMA's clause is now being adopted sporadically in London, by sovereigns like Georgia. ${ }^{50}$

47 Georgia Prospectus (n 41) 79.

48 Buchheit (n 19).

49 Felix Salmon, 'The Buy Side Starts to Bite Back' Euromoney (April 2001).

50 EMCA, Model Covenants for New Sovereign Debt Issues (3 May 2002) <http://www.emta.org/ndevelop/model.pdf > (accessed 19 November 2008). IPMA, Standard Collective Action Clauses (CACs) for the Terms and Conditions of Sovereign Notes (8 October 
New York's response to Ecuador was different. Answering investor demands in its 2003 CAC launch, Mexico included a similar range of provisions in the definition of Reserved Matters, amendable on par with financial terms. The vote required was 75 per cent of principal outstanding, significantly less than unanimity and consistent with the broader objective of deterring holdout litigation. ${ }^{51}$

As with the meeting and engagement provisions, the shift to unanimity does not fit any of the three prevailing explanations for boilerplate change: none of the innovators were big players, none of the early adopters sought to publicize the change to diffuse it or enhance their prestige, the official sector was uninvolved and apparently unaware. The unanimity provisions were negotiated and new-not inadvertent. However, as with committee-style engagement clauses, unanimity's prospects were clearly better for being part of the IPMA clause package.

\section{Conclusions: innovation questions}

Soon after Mexico's CAC launch in 2003, a leading London-based participant in sovereign debt debates of the day noted, ' $\mathrm{t}$ ] he markets would welcome standardization; it is important that these clauses be as uniform as possible... The least desirable outcome would be for a particular issuer's CACs to become a source of competition ... ${ }^{52}$ Yet five years later and despite widespread perception to the contrary among officials and academics, the market is rife with quiet experimentation. In our snapshot focusing primarily on the London market, we found at least five variations on amendment procedures, voting thresholds and creditor coordination mechanics. ${ }^{53}$ Some had roots in financial industry efforts to change market practice, others appeared to migrate from New York, yet others looked original. We also found new evidence that pre-Mexico CACs unearthed since 2003 used diverse, highly customized formulations - unlikely to be the product of inadvertent cutting and pasting. ${ }^{54}$ This pattern of innovation raises new questions for theory and practice.

2004) <http://www.icma-group.co.uk/getdoc/c4a386a7-afc4-47fb-92a5-94f4e651de0a/CACs-Clauses-Section-VII-No-8-Oct-2004PDF.aspx?> (accessed 17 November 2008).

51 Mexico Prospectus (n 21).

52 Robert B. Gray, 'Collective Action Clauses', Remarks Prepared for Delivery at UNCTAD Fourth Inter-Regional Debt Management Conference, Geneva (11 November 2003) 12.

53 Among the differences we do not discuss in detail here are those relating to 'Reserved Matters'-key terms whose amendment requires the highest supermajority. As noted earlier, in addition to payment terms previously subject to unanimity, a range of clauses that could have been modified by simple majority before 2003 were elevated to reserve status. The list of such newly elevated terms has varied among issuers. Most, if not all, of the post 2003 US law sovereign issuances we examined elevated the status or pari passu clause. They did not, however, elevate the status clause's cousin, the negative pledge clause. In the United Kingdom, since 2003, many sovereigns followed the same practice; however, at least two chose to elevate the negative pledge clause instead of status clause. Yet another chose to elevate both the negative pledge and the status clause. These variations may offer important insights into the market participants' understanding of the underlying clauses; however, a detailed analysis is beyond the scope of this article.

54 For example, Lebanon's 1997 issue contains a 75\% amendment and a 75\% quorum threshold, but the latter does not go down at postponed meetings, as had been the custom in the United Kingdom. Even granting that the clause is a product of some formcopying, it matches neither the US nor the UK template. This means either that the drafters came up with a brand new formulation, or that they tried to get the more favourable UK formulation, but had to negotiate down. Neither is inadvertent. Offering Circular, Republic of Lebanon, \$100,000,000, 7.5\% Notes Due 2007 (30 June 1997). 
Contract boilerplate literature suggests that big players drive innovation, occasionally with the assistance of the official sector. But the most innovative recent CACs all came from relatively minor issuers in the sovereign debt market, owing either to their small size or relatively infrequent borrowing. The investment banks that managed the issues were bigger fish, but we saw little hint of a documentation preference pattern among lead managers: one of the leading banks, for example, had at least four different variants of CACs out of London after 2003. The law firms representing issuers were highly respected, but hardly high-volume intermediaries. There was no evidence that innovation was being driven by one or two firms (or lawyers) with a large sovereign practice as appeared to be the case in New York.

Also contrary to theory's predictions, few of the lawyers involved seemed eager to trumpet their documentation practices as innovative or make any overt effort at their diffusion. Most described themselves as simply representing their clients to get the best deal acceptable to both sides. If anything, they were reluctant to have attention drawn to their deals. This pattern contradicts boilerplate theory's view of reputation-driven innovation by large players, and other theories' portrayal of small, disruptive innovators seeking to break into a market. In contrast, Lee Buchheit, a partner at Cleary, Gottlieb in New York who represents many sovereign issuers, exemplifies theory: he has a large sovereign practice, regularly publishes articles on his clients' innovations, and brings them to the attention of the official sector. ${ }^{55}$

The story of government-driven innovation-the Official Sector Explanation, which dominated accounts of Mexico's CAC launch-also fails in this case. Conversations with officials and market participants revealed no IMF or US Treasury involvement in the recent deals, and a nearly complete drop-off in high-level official engagement on CACs. The IMF operational guidance still encourages states to adopt CACs (defined as including, but not limited to, majority amendment and majority enforcement) as an element of good debt management practices during annual economic policy consultations, ${ }^{56}$ but it does not delve into drafting particulars. The Fund also offers occasional updates on CAC implementation ${ }^{57}$; however, these have become less frequent in recent years. In the absence of new emerging market debt crises, other policy priorities took over.

On the other hand, the influence of trade associations and their efforts to diffuse the Principles bears further study. Two terms sporadically adopted in London-creditor committees and unanimity to amend litigation-related terms-were part of a new template drafted by IPMA/ICMA and supported by the Institute of International Finance (IIF). The industry language has become part of the mix considered more or less critically

55 For example, Lee C. Bucbheit and Jeremiah S. Pam, 'Uruguay’s Innovations' (2004) 19 J Intl Bank Regul 28; Lee C. Buchheit and Elizabeth Karpinski, 'Grenada’s Innovations' (2006) 21 J Intl Bank Regul 227; 'Belize's Innovations' (2007) Butterworths J Intl Banking \& Fin 278.

56 Berhnard Fritz-Krockow and Parmeshwar Ramlogan (eds), Internatoinal Monetary Fund Handbook: Its Functions, Policies and Operations (2007) 64. <http://www.imf.org/external/pubs/ft/imfhb/eng/handbook.pdf> (accessed 19 November 2008).

57 International Monetary Fund, Global Financial Stability Report: Market Developments and Issues, ch 1 (2006) 46 <http:// www.imf.org/external/pubs/ft/GFSR/2006/01/pdf/chpl.pdf> (accessed 19 November 2008). 
by London-based counsel in documenting an emerging market sovereign bond. However, there is limited evidence that industry-supported terms have become the new boilerplate.

Would CACs have taken hold in New York in the absence of official pressure, much as they had in an early subset of London issues under New York law? Lawyers, officials and trade association representatives involved in the shift have variously raised this possibility with us; however, all seemed to agree that once the official sector adopted the clauses as a policy item in the mid-1990s, spontaneous or 'stealth' innovation was not an option. If nothing else, official attention made unanimity salient and CACs deviant in New York.

Recent experience also raises questions concerning the difference between New York and London markets. Some of the lawyers we interviewed suggested that London was simply more flexible than New York. This seems plausible inasmuch as we have seen a surprising level of adoption of New York drafting conventions in London, with no comparable breadth of diffusion of London forms in New York. ${ }^{58}$ London-based lawyers involved in recent issues noted that they researched official and trade association models, along with precedents from both English and New York law contracts. They appeared to regard all four as equally useful — but none more authoritative than the other. They regarded Mexico's 2003 issue as less of a revolution than a data point. If this attitude turns out to be widespread, it may indicate a new level of market integration and pluralism: creative lawyers mix and match boilerplate from diverse sources, and alter it to meet their clients' needs. We may also be seeing a decline of independent New York and London styles of drafting contracts.

The apparent difference in innovation practices between the London and New York markets requires further explanation. Our contacts suggested a number of possible factors that might account for the difference, though none appeared definitive. Despite mergers, alliances and expansions into each other's markets, US and UK firms have different cultures and business models. The London market is also more concentrated. But none of these features clearly favour a specific model of innovation. One senior lawyer suggested the difference may lie in training. Most US lawyers doing sovereign work have a securities or corporate law background, which makes them more sensitive to disclosure and fiduciary concerns, and perhaps more hesitant to experiment. UK lawyers in the field are more likely to come from banking law and contracting. Our findings thus far do not give us enough to speculate as to which of these possible explanations, if any, are driving the apparent differences in contract innovation. But there is enough to suggest that it is dangerous to assume that the dynamics of innovation in the two markets are the same.

In the end, we come full circle to the definition of boilerplate, how it comes into being, how it changes and how it relates to the bespoke terms. In the case of CACs, we saw a standard term that became dislodged under official pressure, but that in many respects failed to re-standardize around a new model. It is uncertain whether we are witnessing

58 Grenada's New York law issuance is an exception: Buchheit, representing Grenada, adopted the English law convention of vesting individual holders' right to sue with the trustee. 
an interim 'period of ferment' en route to new boilerplate, or a longer term move away from standardization and to customization for a subset of sovereign bond terms. Early boilerplate theories noted that so-called boilerplate contracts contain some combination of customized and standardized terms. Recent experience in London suggests that terms may, depending on circumstances, move in and out of being customized or standardized. This does not rule out an element of inadvertence in the migration of truly standardized terms; future research should help distinguish inadvertent diffusion, deliberate boilerplate innovation and customization.

In March 2007, Slovenia issued $€ 1$ billion in notes that included majority modification provisions, the option of amendment at a meeting or by written resolution, and an engagement clause providing for creditor committees on the industry model. The issue was governed by Slovenian law. While we were unable to ascertain the prior state of Slovenian law boilerplate, we suspect that its 2007 contracts were the product of quiet innovation within the past decade. 